(C) The Author(s), 2021. Published by Cambridge University Press on behalf of the Arizona Board of Regents on behalf of the University of Arizona. This is an Open Access article, distributed under the terms of the Creative Commons Attribution licence (http://creativecommons.org/licenses/by/4.0/), which permits unrestricted re-use, distribution, and reproduction in any medium, provided the original work is properly cited.

\title{
RADIOCARBON DATING OF ST. GEORGE'S ROTUNDA IN NITRIANSKA BLATNICA (SLOVAKIA): INTERNATIONAL CONSORTIUM RESULTS
}

\section{Pavel P Povinec $^{1 *(1)} \cdot$ Alexander Cherkinsky $^{2}$ (D) - Jozef Dorica ${ }^{3} \cdot$ Irka Hajdas $^{4}$ (D)}

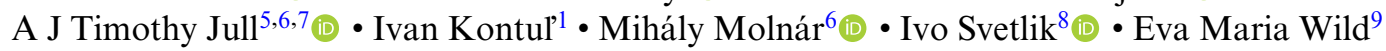

\author{
${ }^{1}$ Department of Nuclear Physics and Biophysics, Faculty of Mathematics, Physics and Informatics, Comenius \\ University, Bratislava, Slovakia \\ ${ }^{2}$ Center for Applied Isotope Studies, University of Georgia, Athens, GA, USA \\ ${ }^{3}$ Restauro Complet s.r.o., Žilina, Slovakia \\ ${ }^{4}$ Laboratory of Ion Beam Physics, ETH Zürich, Switzerland \\ ${ }^{5}$ Accelerator Mass Spectrometry Laboratory, University of Arizona, Tucson, AZ, USA \\ ${ }^{6}$ Isotope Climatology and Environmental Research Centre, Institute for Nuclear Sciences (ATOMKI), Hungarian \\ Academy of Sciences, Debrecen, Hungary \\ ${ }^{7}$ Department of Geosciences, University of Arizona, Tucson, AZ, USA \\ ${ }^{8}$ Nuclear Physics Institute, Czech Academy of Sciences, Prague, Czech Republic \\ ${ }^{9}$ VERA Laboratory, Isotope Physics, Faculty of Physics, University of Vienna, Vienna, Austria
}

\begin{abstract}
An international consortium of radiocarbon $\left({ }^{14} \mathrm{C}\right)$ laboratories was established to date the origin of the St. George's Rotunda in Nitrianska Blatnica (Slovakia), because its age was not well established in previous investigations. Altogether, 20 samples of wood, charcoal, mortar and plaster were analyzed. The ${ }^{14} \mathrm{C}$ results obtained from the different laboratories as well as between the different sample types were in good agreement, resulting in a ${ }^{14} \mathrm{C}$ calibrated age of $783-880$ AD $\left(94.2 \%\right.$ probability) for the Rotunda. Although the ${ }^{14} \mathrm{C}$ results have very good precision, the specific plateau-shape of the calibration curve in this period caused the wide range of the calibrated age. The probability distribution from OxCal calibration shows, however, that about $86 \%$ of the probability distribution lies in the period before $863 \mathrm{AD}$, implying that the Rotunda could have been constructed before the arrival of Constantine (St. Cyril) and St. Methodius to Great Moravia. The Rotunda thus probably represents the oldest standing purpose-built Christian church in the eastern part of Central Europe.
\end{abstract}

KEYWORDS: accelerator mass spectrometry, charcoal, mortar, Nitrianska Blatnica, plaster, radiocarbon dating, St. George's Rotunda, wood.

\section{INTRODUCTION}

St. George's Rotunda, a small country church made from stones and mortar (Figure 1), is located in western Slovakia about $5 \mathrm{~km}$ north of the Nitrianska Blatnica village $\left(48^{\circ} 35^{\prime} 05^{\prime \prime} \mathrm{N}\right.$; $\left.17^{\circ} 57^{\prime} 9^{\prime \prime} \mathrm{E}\right)$, in a forest on a small hill (433 $\mathrm{m}$ a.s.1.) at the foothill of Marhát peak (748 m a.s.1.) of the Považský Inovec mountains. The regional town of Nitra is about $35 \mathrm{~km}$ southeast, and the capital city Bratislava is about $100 \mathrm{~km}$ southwest (Figure 2).

Over the centuries, the Rotunda experienced several reconstructions which changed its shape and visage; therefore, its origin has been disputed. The largest reconstructions were carried out in 1777 when a new tower was built on the west side of the Rotunda, large windows and new vaults were added, and with the new facade it got a Baroque look (Figures 1, 3, 4).

\section{Short Historical Background}

Central Europe in 9th-10th centuries was place of many struggles between Franks, Slavs, and Hungarians, who were fighting for new territories and establishing regional principalities (Goldberg 2006). One example is the formation of the Slavic Nitra and Moravia

\footnotetext{
*Corresponding author. Email: pavel.povinec@uniba.sk
} 

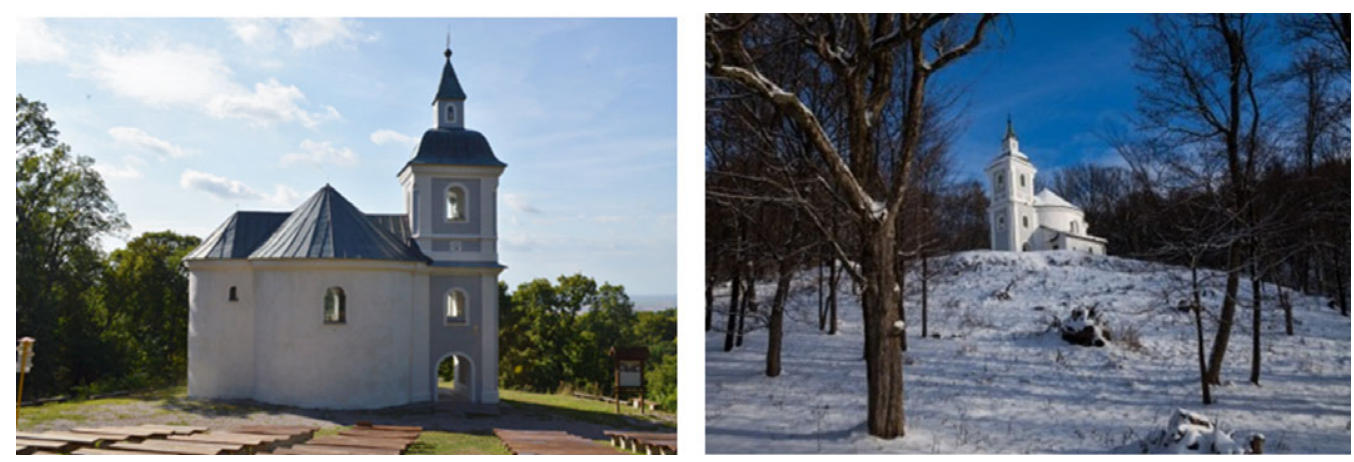

Figure 1 Northern (left) and southwestern (right) views of the Rotunda St. George in Nitrianska Blatnica (Slovakia).

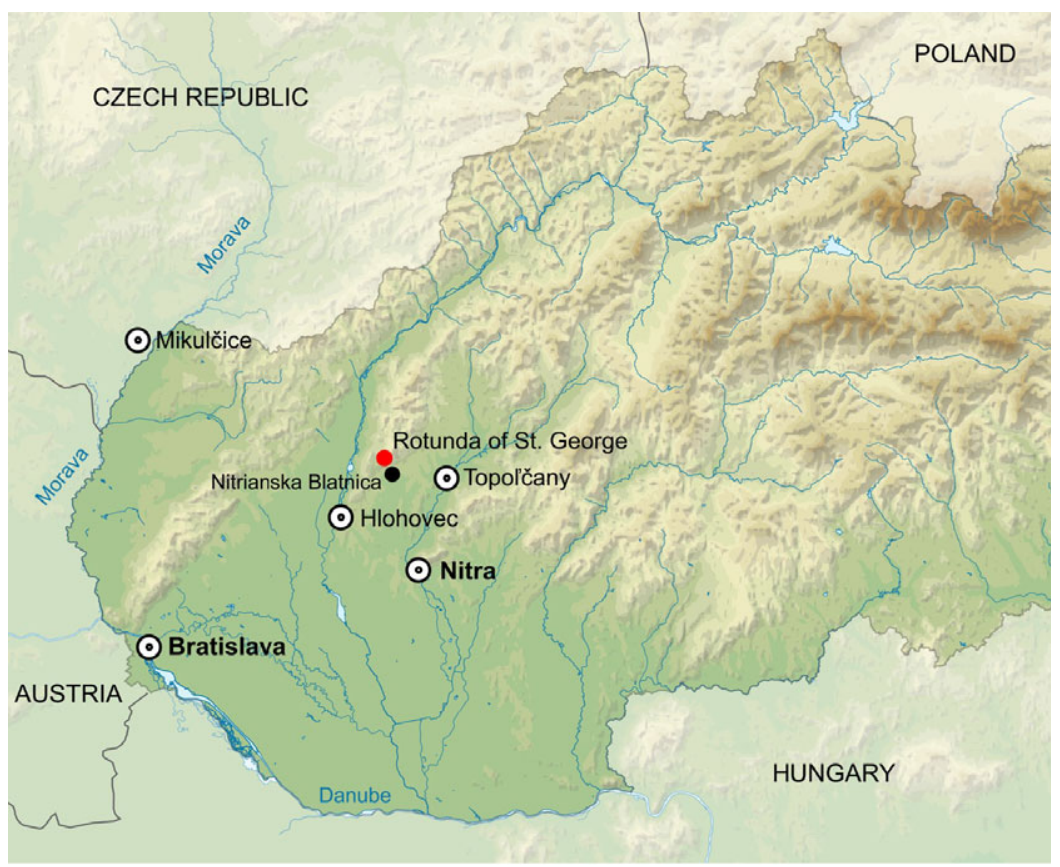

Figure 2 Map of western Slovakia with location of St. George's Rotunda.

principalities (east and west of the Moravia river, respectively), which were combined in 833 to form a nucleus of Great Moravia (Spiesz and Caplovic 2006). Later, in 895 a Principality of Hungary was established in the Carpathian Basin, and in 1000 King Stephen I formed the Kingdom of Hungary. An important part of these new developments was also the progression of Christianization from the west to the east, with competing interests between the centers of Rome and Constantinople (Terry and Gallagher 2017).

The first written source about Christianization of Slavs is a mention of consecration of a church in 828 in Nitra (Anonymous 870). However, many other activities were carried out in the Nitra 

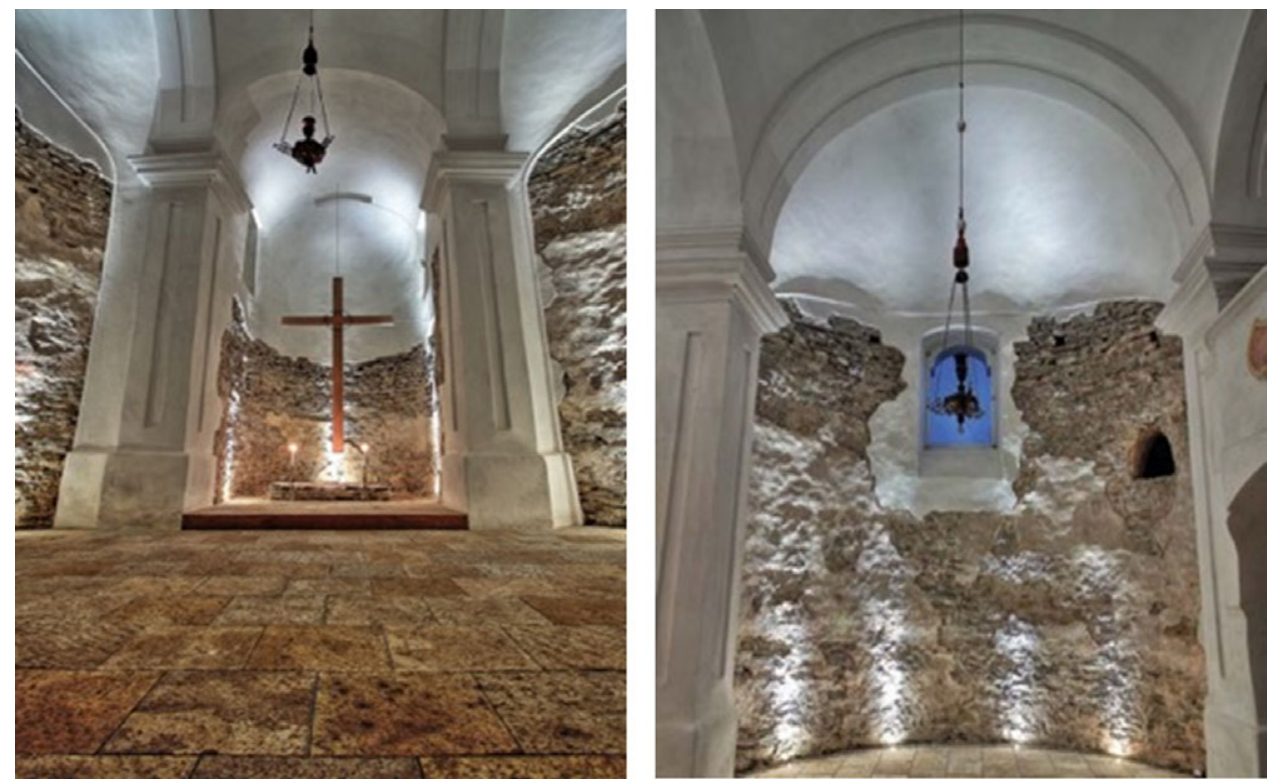

Figure 3 Interior view of the Rotunda (left) and the nave's southern wall with the original pre-Romanesque window opening after the restoration (right).

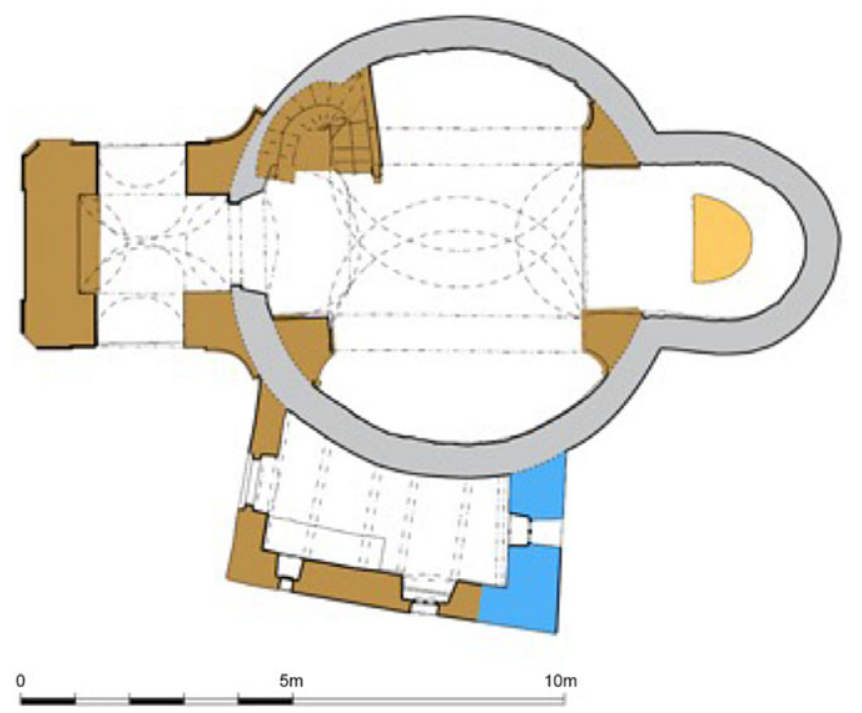

Figure 4 Floorplan of the Rotunda with construction phases: pre-Romanesque (gray), Renaissance (blue), Baroque (brown), 19th century (yellow). (Please see electronic version for color figures.)

principality, including for example the production of iron. One such site (about $25 \mathrm{~km}$ north of Nitra, under the Marhát peak) is mentioned in the 16th century document (Lukačka 2002, 2011), indicating that the local settlement called Sarfew belonged in 1185 to Stojslav of the Poznan dynasty (with approval of Bela III, king of Hungary). Archaeological investigations 
carried out by Ruttkay (1977) showed that a court settlement at the plain site called Púst, already existed in the 9th-10th century, which developed in the 11th-13th century into a small village with a cemetery. The village was mainly engaged in iron production from local sources. Later the village disappeared, probably due to exhaustion of the local iron ore, so people left the site for more comfortable villages formed in the valley. This is the place where the St. George's Rotunda was built, which is the main objective of the present work. After people left the Pús' site, the Rotunda fell into neglect and gradually became a ruin.

In the Renaissance period, during the decade of 1530-1540, restoration work and revitalization of the Rotunda were carried out. At this time, the damaged walls were repaired, and the building was roofed again. In the apse a new concha was created. The interior of both the apse and the nave were newly plastered (Ragač 2009). In the second half of the 16th century, probably under the parish of Nitrianska Blatnica, a fraternity of St. Francis was established at the site with permission of a papal bull of Pope Sixtus V, which was issued in 1586. The local fraternity was connected to the Franciscan convent at Hlohovec town (about $25 \mathrm{~km}$ southwest of the Rotunda). It is most likely that Franciscans, with local people made pilgrimages to worship at the memorial to St. George on his holy day, April 24. Therefore, sometime during this period, the tradition of the St. George pilgrimage to the Rotunda was established. The annual pilgrimage is still held up to the present day, which makes this about 430-year-old tradition to visit the St. George's Rotunda site the oldest continuous place of pilgrimage in Slovakia. At the end of the 16th and possibly the beginning of the 17th century, a small hermitage was added to the south wall of the Rotunda where a hermit would live (Figures 1 and 4), who also took care about the Rotunda. Significant repair works were carried out on the Rotunda in 1777, which obliterated previous Renaissance repairs.

The original shape of the apse was altered, and corner pillars were added. The nave was extended with pillars, and above, in the interior of the nave and the apse, a new masonry brick vaulting was constructed. In the walls of the nave, large window openings were cut. On the east side, above the entrance to the nave, a masonry empora was built. On the west side, near the original entry to the Rotunda from the exterior wall, a new square-shaped tower was built. These radical modifications to the architecture gave a Baroque look to the Rotunda (Figures 1 and 4). At the same time, repair work was also carried out on the hermitage. After these restoration works, the Rotunda received a Baroque wooden polychrome altar, which was made in 1693. Later, probably in the year 1782, a picture depicting St. George battling with the Dragon was painted for the altar. In the second half of the 18th century, on the slope to the Rotunda, a relatively large building was constructed for the Hermitage school. The school, together with the Rotunda, is indicated on a military map from the years $1782-1785$. The school was probably famous as it was attended also by Ján Scitovský (1785-1866), later Hungarian Primate and Archbishop of Esztergom. After the demise of the school around the start of the 19th century, the building served as a forester's cottage, until its demolition in 1965. Probably around the turn of the 18th century, a stone sculpture Golgotha was positioned on the top of the slope (460 m a.s.1.) near the Rotunda. Further repair works to the Rotunda and altar were carried out in 1846. In the following years of the 19th and 20th centuries, only minimum repairs were done, mostly on the main roof. Unfortunately, during repairs in 1968, layers of original plaster work were removed from the internal walls of the Rotunda, which damaged its original character. Also, the Baroque plaster from the tower was removed, with the exception of the south wall, where fragments of the plaster with painting were retained. 


\section{Summary of Archaeological and Restoration Investigations}

On the basis of a Canonical visit in 1559, the Rotunda of St. George was registered in the Central List of the Monument Fund of Slovakia as a Renaissance church built in 1541. In 1973, after the initiative of the Redemptorist F. Jurík, the priest at Nitrianska Blatnica, the Monuments Board of Slovakia issued instructions for reparation of the Rotunda. The first results of these investigations which were carried out in 1973-1975 (Rejthar 1975), and especially the archaeological research carried out in 1974-1980 (Ruttkay 1975, 1977, 1980) indicated a Romanesque origin of the Rotunda. The archaeological research also included the immediate Rotunda surroundings (a cemetery), and a much wider area further around the Rotunda, including a meadow presently called Púst, situated on the southwest side of the Rotunda, close to a rocky outcrop of the mountain Marhát. This research brought new discoveries, suggesting that the Rotunda and its surroundings are much older than previously thought. The settlement discovered at Púst could originate at the beginning of the 9th century, and its existence could be traced to the 10th century. Remains of two grand courtyards with palisade defense work were discovered, and even an older courtyard which ceased to exist in the 9th century. A later, smaller courtyard was in existence which disappeared during the course of the 10th century. The settlement developed as a scattered grouping around the Rotunda (a small village), which disappeared during the 13th century. Researchers also discovered a charcoal oven, a large grinding stone, and many pits where iron ore was mined. Other finds clearly indicated that iron production was the main economic strength of the settlement. Presumably, this brought prosperity to the local owners and created a wealth and social importance that enabled them to build a stone church. At the same time the preserved standing rotunda bears witness to the high level and extent of Christianity among the inhabitants of this land. A cemetery found around the Rotunda included more than 40 graves with several superposition of skeletons. In one of the graves (at the 3rd layer), a coin of King Koloman (1095-1114) was found, thus dating the origin of the grave to around the middle of the 11th century (Ruttkay 1977, 1980). This timing was therefore accepted as a possible origin of the Rotunda as well. Later Ruttkay (1998) suggested that the foundations possibly could come from the 9th-10th century (in coincidence with the origin of the local settlement), and the above-ground masonry was newly built during the 11 th century.

In 2001, during reconstruction work, it was found on the northern part of the exterior wall that the material used for the basement of the Rotunda is the same as in the above basement wall, up to $1.2 \mathrm{~m}$ height (Bóna and Barta 2015). A sample of mortar taken from the external wall was radiocarbon $\left({ }^{14} \mathrm{C}\right)$ dated to $998 \pm 26 \mathrm{BP}$, with calibrated ages of $991-1052 \mathrm{AD}$ (at $59.2 \%$ probability) and 1082-1152 AD (at 36.2\% probability).

During 2009-2016, a further restoration research project was carried out for the interior and exterior of the Rotunda (Dorica 2015, 2017). It was found that the stone walls in layers were formed from local hammer-faced stones, and a large part of the preserved original aboveground masonry of the nave of the Rotunda was high from $\sim 560 \mathrm{~cm}$ to $\sim 650 \mathrm{~cm}$ (Dorica 2017). Further important findings included: (i) a discovery of original, pre-Romanesque type of window opening (Figure 3); (ii) identification of the oldest type of masonry, which underlines the uniqueness of the stone wall above ground in the nave and in the apse; (iii) finding of preserved plaster fragments from the 9th-13th century. On the second layer, two consecration crosses were found, one almost whole (Figure 5), the other one just a preserved fragment. On the southeast part of the wall of the nave, fragments of 

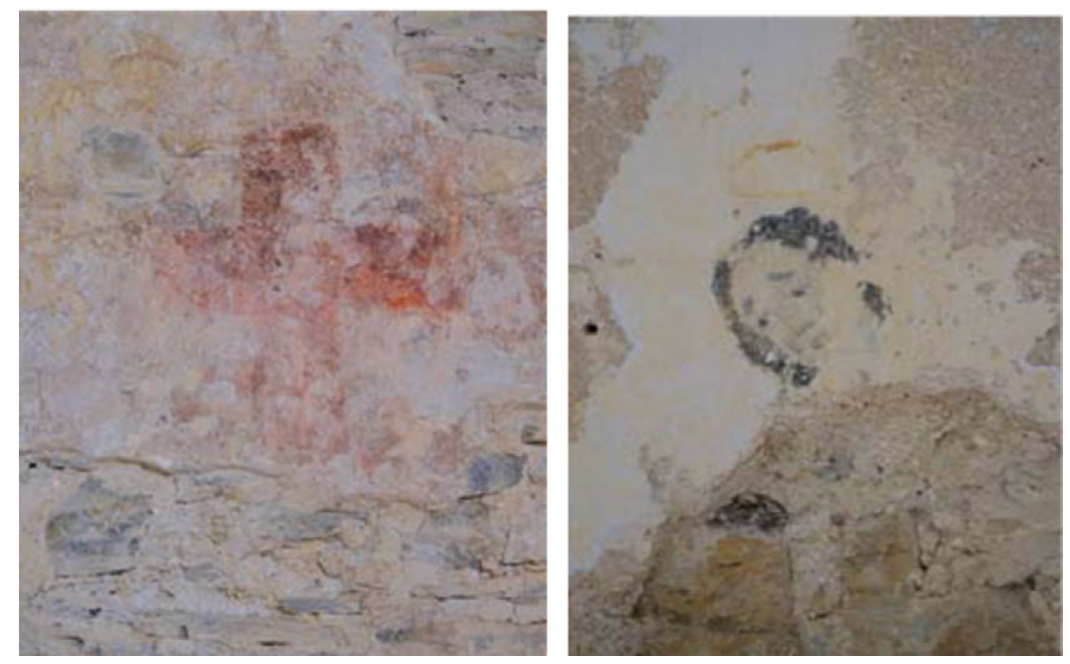

Figure 5 Detail of the consecration cross (left) situated on the northern wall, where the plaster sample P2 (1050) was taken, and the detail of the wall painting (probably the 1st half of the 17th century) of an unknown saint (right) where the wood sample W4 (1047) was found in the hole under the missing plaster.

wall-paintings were discovered, showing a head and part of the garment of an unknown saint (Figure 5). The condition of the painting suggests that it was most likely created at the end of the 16th century, possibly at the beginning of the 17 th century, coinciding with the supposed activity of the brotherhood of St. Francis.

These findings, together with others discussed later, indicated that the Rotunda could be older than the 11th century as previously estimated, and a possible origin was expected to be in the 9th century (Dorica 2015). Following these developments, a new archaeological interpretation was also in favor of the 9th century (Ruttkay 2014, 2015).

Fortunately, during the restoration works samples of wood and charcoal were found in the walls, which together with samples of mortar and plaster collected from the inner walls, could be used to determine the age of the Rotunda by ${ }^{14} \mathrm{C}$ dating. Because of the archaeological and historical significance of the Rotunda, not only in respect to Slovakia but also to Central and Eastern Europe, it was decided that an international consortium will be formed, consisting of independent world-renowned ${ }^{14} \mathrm{C}$-dating laboratories.

\section{SAMPLES}

All sampling was carried out in the Rotunda's interior, as the outside walls have recently been covered with plaster and white paint.

In the course of restoration activities, small samples of wood $(0.1-10 \mathrm{~g})$ and charcoal $(0.01-1 \mathrm{~g})$ were found in several places after opening the interior stone walls. The samples were well fixed in the mortar that filled the space between the stones. The samples were found a few meters above the present floor, at depths of $2-30 \mathrm{~cm}$ inside the stone walls, with wall thickness from $\sim 68 \mathrm{~cm}$ to $\sim 73 \mathrm{~cm}$. One of the wood samples was only a small piece of a thin sprig. All collected 
(a)

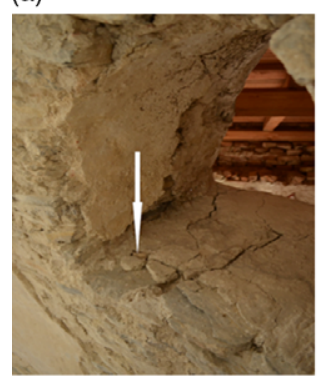

(b)

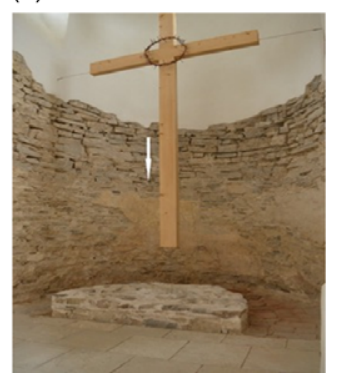

(c)

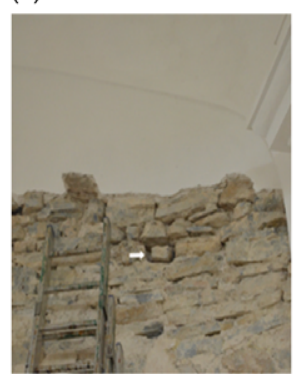

(d)

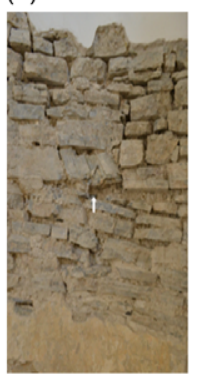

(e)

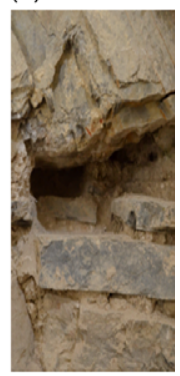

Figure 6 Examples of sampling sites in the Rotunda interior: wood sampling point W6 (1041) in the pre-Romanesque window (a); charcoal C2 (1042) point at the apse closing (b); mortar M1 (1049) point at the northeastern part of the nave (c); mortar M2 (1045) point at the eastern part of the apse wall, and in detail (e).

pieces of wood and charcoal could represent only 1 or 2 annual tree rings. It is expected that the wood and charcoal samples fell into the mortar and plaster during preparation work.

The collected wood and charcoal samples together with mortar and plaster samples were used for ${ }^{14} \mathrm{C}$ dating in consortium laboratories in such a way that each sample (if there was enough material) was analyzed independently at least by two laboratories.

\section{Wood Samples}

Sample W1 (1043): A small sprig ( $2 \mathrm{~mm}$ in diameter and $30 \mathrm{~mm}$ long) found in surface plaster at the apse (sampled 31/7/2012), where later also plaster sample, P4 (1062), was collected.

Sample W2 (1068): Small pieces of wood found in the old mortar on the top of southeastern part of the nave wall (sampled 1/8/2012).

Sample W3 (1044): A small piece of wood found in the old mortar in the southeastern nave wall, left from the old painting fragments (sampled 29/8/2012).

Sample W4 (1047): A small piece of wood found in the old mortar in the southeastern nave wall, in the place of the missing plaster, close to the painting of the saint (sampled 29/8/2012).

Sample W5 (1067): Small pieces of wood found in the old mortar at the southwestern part of the nave (sampled 10/9/2012).

Sample W6 (1041): A small piece of wood found in the old mortar on the parapet of the preRomanesque type of window opening, Figure 6a (sampled 10/10/2015).

\section{Charcoal Samples}

Sample C1 (1048): Small pieces of charcoal found in mortar (1061) at the southwestern part of the apse wall, $44 \mathrm{~cm}$ above the present floor, $87 \mathrm{~cm}$ from the pillar (sampled 29/8/2012).

Sample C2 (1042): Small charcoal pieces found in the old mortar at the apse closing, Figure $6 \mathrm{~b}$ (sampled 10/5/2016). 
Sample C3 (1046): Small charcoal pieces found in the old mortar at the apse closing, close to the place where charcoal sample (1042) was found (sampled 10/5/2016).

\section{Mortar Samples}

The mortar samples were also taken from the internal parts of the stone walls. The stone walls were built from local quarry stones up to about $6.5 \mathrm{~m}$ height, forming an anti-conical arrangement about $70 \mathrm{~cm}$ thick. This type of construction made the walls very stable even without a roof, lasting probably for several centuries. On the other hand, such an arrangement caused difficulties when opening the wall for collecting mortar samples from its interior. In the central parts of the walls the mortar was absent.

Sample M1 (1049): The sample taken at the northeastern part of the nave at the height of $440 \mathrm{~cm}$ from the present floor and $80 \mathrm{~cm}$ from the boundary of the baroque coatings at the depth of $20 \mathrm{~cm}$, Figure 6c (sampled 10/5/2016).

Sample M2 (1045): The sample was taken from the eastern wall of the apse at the height of $210 \mathrm{~cm}$ from the present floor at the depth of 10-20 cm, Figure 6e (sampled 1/9/2016).

Sample M3 (1069): The sample was taken from the western wall of the apse at the height of $208 \mathrm{~cm}$ from the present floor at the depth of 10-15 cm (sampled 1/9/2016).

Sample M4 (1061): The sample was taken from the socle at the southwestern part of the apse wall, $44 \mathrm{~cm}$ above the floor, $87 \mathrm{~cm}$ from the pillar (sampled on 29/8/2012). Charcoal sample C1 (1048) was found inside the mortar (sampled 1/9/2016).

Sample M5 (1063): The sample was taken from the left-side of the apse wall, $210 \mathrm{~cm}$ from the floor and $20 \mathrm{~cm}$ in depth (sampled 10/5/2016).

Sample M6 (1064): The sample was taken from the right-side of the apse wall, $208 \mathrm{~cm}$ from the floor and $15 \mathrm{~cm}$ in depth (sampled 10/5/2016).

Sample M7 (1070): The sample was taken at the depth of $8 \mathrm{~cm}$ at the southwestern part of the apse wall, $72 \mathrm{~cm}$ above the point where the sample M4 (1061) was taken.

\section{Plaster Samples}

The plaster samples represented surface layers of undisturbed wall coatings. The first layer of the coating, covering just rough stone surface was made of the same mortar which was used for wall constructions. The concreting sand was of different fractions, causing irregular plaster structures of different thickness. The second coating layer of 1-2 cm thickness was made with fine sand, covered at some places with painting decorations (consecration crosses). In the southeastern part of the nave, a third layer of the coating layer was found, probably used for reparation of small, damaged parts of the wall.

Sample P1 (1065): The sample of coarse-grained plaster having signs of repair was taken from the southwestern part of the nave at the height of $105 \mathrm{~cm}$ from the present floor, and $100 \mathrm{~cm}$ from the empora pillar, covering the rough stone (sampled 10/5/2016).

Sample P2 (1050): The sample represents the second plaster layer (made of fine sand) taken from the southwestern part of the nave at the height of $185 \mathrm{~cm}$ from the present floor, and 
$110 \mathrm{~cm}$ from the empora pillar. On the preserved parts of the wall there are remnants of pigments from painting decorations, including one complete and one fragment of consecration crosses (sampled 10/5/2016).

Sample P3 (1066): The sample was taken from the southeastern part of the nave wall at the height of $60 \mathrm{~cm}$ from the floor and $80 \mathrm{~cm}$ from the empora pillar. It represents a plaster used for a reparation of the damaged coating (sampled 10/5/2016).

Sample P4 (1062): The sample was taken from the surface of the apse wall which was introduced during reparation works (sampled 1/9/2016), where previously wood sample W1 (1043) was found.

\section{METHODS}

\section{Radiocarbon Analyses}

When enough sample material was available, the samples were divided and sent to at least two ${ }^{14} \mathrm{C}$ laboratories for independent ${ }^{14} \mathrm{C}$ analyses. Each laboratory used its own sample pretreatment and measurement methods. All laboratories (except Bratislava) used accelerator mass spectrometry (AMS) for ${ }^{14} \mathrm{C}$ measurements. The first ${ }^{14} \mathrm{C}$ measurements of the Bratislava group (for a rough estimation of the age of wood and charcoal samples) were carried out using a small-volume gas proportional counter. Later, in the framework of the consortium, the Bratislava group also prepared graphite targets for AMS measurements which were carried out at the Debrecen and Athens laboratories.

The participating laboratories normalized their ${ }^{14} \mathrm{C}$ results with oxalic acid standard reference material (HOX II SRM 4990-C) from the National Institute of Standards and Technology (NIST, Gaithersburg, USA) (Schneider et al. 1995). Carbon dioxide prepared from fossil carbon sources was used as a background sample. The measured activities and uncertainties were calculated following Stuiver and Polach (1977) convention.

\section{Comenius University Laboratory in Bratislava}

Standard procedures applied in the Bratislava ${ }^{14} \mathrm{C}$ laboratory were used for pretreatment of analyzed wood and charcoal samples. The selected samples, after visual control for possible impurities, were (because of small sample size) treated using ABA (acid-base-acid) method (Gupta and Polach 1985) - 24 hr treatment in $4 \% \mathrm{HCl}$ at $80^{\circ} \mathrm{C}$, followed by $24 \mathrm{hr}$ treatment in $4 \% \mathrm{NaOH}$ at $80^{\circ} \mathrm{C}$, and finally $24 \mathrm{hr}$ treatment in $4 \% \mathrm{HCl}$ at $80^{\circ} \mathrm{C}$.

The pretreated wood and charcoal samples were then combusted at $950^{\circ} \mathrm{C}$ in a quartz tube with oxygen flow. The obtained carbon dioxide after purification from electronegative impurities was then used for preparation of methane in a reactor filled with background hydrogen and ruthenium catalyst $\left(0.5 \% \mathrm{Ru}\right.$ on $\left.\mathrm{Al}_{2} \mathrm{O}_{3}\right)$, heated to $480^{\circ} \mathrm{C}$ (Povinec 1972). Depending on the sample size, either a large volume (Povinec 1978) or small volume (Povinec 1992) proportional counters were used for ${ }^{14} \mathrm{C}$ counting (using $>2 \mathrm{~g}$ or $0.2 \mathrm{~g}$ of carbon samples, respectively).

Stable isotope ${ }^{13} \mathrm{C} /{ }^{12} \mathrm{C}$ ratios of analyzed samples were measured in prepared $\mathrm{CO}_{2}$ samples using a conventional mass spectrometer. The results were expressed as $\delta^{13} \mathrm{C}$ with respect to the PDB standard (uncertainties were less than $0.1 \%$ ). The resulting ${ }^{14} \mathrm{C}$ data were corrected for isotope fractionation. 
The mortar and plaster samples were too small for gas proportional counting; therefore, they were analyzed by AMS. After cryobreaking (sequential cooling with liquid nitrogen and heating to $80^{\circ} \mathrm{C}$ ), the samples were gently crushed and sieved. $\mathrm{CO}_{2}$ was evolved from the samples in glass vacuum line by hydrolysis using phosphoric acid. The $\mathrm{CO}_{2}$ resulting after the first 6 seconds of hydrolysis was collected in liquid nitrogen (to assure enough sample for graphitization), and after purification it was used for preparation of graphite targets. They were prepared using the hydrogen graphitization method in closed reactors with heated iron catalyst and cryogenic water trap (Povinec et al. 2015; Kontul et al. 2017). Prepared graphite samples were then sent for AMS measurement to Debrecen (Molnár et al. 2013b) and Athens laboratories.

\section{ETH Laboratory in Zurich}

Prior to more sophisticated analyses, the bulk mortar sample M1 (1049) was analyzed for ${ }^{14} \mathrm{C}$ and ${ }^{13} \mathrm{C}$ content. The mortar samples were then dry sieved, and after grain size separation, the fraction of 63-45 $\mu \mathrm{m}$ was used for sequence dissolution in 3-sec intervals, with subsequent $\mathrm{CO}_{2}$ collection in liquid nitrogen. Released $\mathrm{CO}_{2}$ was collected in four separate fractions, plus a bulk $\mathrm{CO}_{2}$ sample. The analytical method of ${ }^{14} \mathrm{C}$ dating of mortar at ETH Zurich was described in detail by Hajdas et al. (2020). In the case of St. George's Rotunda samples, the collected $\mathrm{CO}_{2}$ from different fractions contained very small amounts of carbon (tens of micro grams), therefore AMS analysis was carried out using a gas ion source of MICADAS AMS system (Ruff et al. 2010). The charcoal sample was treated by ABA method (Hajdas 2008) and analyzed by AMS as a graphite sample.

\section{Institute of Nuclear Physics Laboratory in Prague}

Standard procedures applied in the Prague ${ }^{14} \mathrm{C}$ laboratory were used for pretreatment of analyzed wood samples. After visual checks of samples for possible impurities, the samples were treated using already described ABA method. The prepared samples were then sealedoff under dynamic vacuum into quartz ampoules with addition of $\mathrm{CuO}$. The samples were then combusted at temperature of $900^{\circ} \mathrm{C}$. Purified carbon dioxide was then introduced into a graphitization reactor, containing clean zinc as a reducing agent (Molnár et al. 2013a; Rinyu et al. 2013, 2015). Prepared graphite samples were finally vacuum sealed in glass ampoules and sent for AMS measurements in the Debrecen laboratory (Molnár et al. 2013b; Orsovszki and Rinyu 2015).

\section{Institute for Nuclear Sciences Laboratory in Debrecen}

Standard procedures applied in the Debrecen ${ }^{14} \mathrm{C}$ laboratory were used for pretreatment of analyzed wood and charcoal samples. The samples were treated with the ABA method. The prepared samples together with $\mathrm{CuO}$ were then sealed under vacuum into quartz tubes. The samples were combusted at $900^{\circ} \mathrm{C}$. The produced $\mathrm{CO}_{2}$ after purification was then introduced into a glass graphitization reactor, containing clean zinc as a reducing agent (Molnár et al. 2013a; Rinyu et al. 2013, 2015). AMS measurements were carried out using the MICADAS (Ionplus, Dietikon, Switzerland) spectrometer (Molnár et al. 2013b; Orsovszki and Rinyu 2015). The NIST HOX II SRM 4990-C standard reference material was used for calibration (Schneider et al. 1995). Fossil carbon dioxide was used as a background sample. The measured ${ }^{14} \mathrm{C}$ activities and their uncertainties are expressed as BP ages using the Stuiver and Polach (1977) convention. 


\section{University of Arizona Laboratory in Tucson}

Standard procedures applied at the University of Arizona AMS Laboratory were used for pretreatment of analyzed wood and charcoal samples. Charcoal samples were pretreated using standard ABA method. In the case of wood samples, following standard ABA pretreatment, the samples were bleached with sodium chlorite solution and alpha-cellulose was extracted using sodium hydroxide (Lange et al. 2019). Both the pretreated charcoal and extracted alpha-cellulose were combusted in quartz tubes with $\mathrm{CuO}$. The resulting $\mathrm{CO}_{2}$ was then purified and graphitized using the standard zinc-iron graphitization method. The prepared graphite samples were measured by AMS system with 3 MV NEC Pelletron accelerator (Jull et al. 2006, 2008). The measured ${ }^{14} \mathrm{C} /{ }^{13} \mathrm{C}$ ratio was evaluated using SRM4990 (oxalic-I) and 4990C (oxalic-II) standard materials and corrected for $\delta^{13} \mathrm{C}$ measured by an isotope mass spectrometer.

\section{University of Georgia Laboratory in Athens}

Standard procedures applied in the Athens ${ }^{14} \mathrm{C}$ laboratory were applied for pretreatment of analyzed wood and charcoal samples using the ABA method. The samples were then combusted and resulting carbon dioxide was cryogenically purified (from other reaction products) and catalytically converted to graphite using the method of Vogel et al. (1984). Graphite ${ }^{14} \mathrm{C} /{ }^{13} \mathrm{C}$ ratios were measured using the CAIS $0.5 \mathrm{MeV}$ accelerator mass spectrometer (NEC, Middleton, USA). The sample ratios were compared to the ratio measured from the Oxalic Acid I (NBS SRM 4990). The sample ${ }^{13} \mathrm{C} /{ }^{12} \mathrm{C}$ ratios were measured separately using a stable isotope ratio mass spectrometer and expressed as $\delta^{13} \mathrm{C}$ with respect to PDB (uncertainties were less than $0.1 \%$ ). The obtained ${ }^{14} \mathrm{C}$ results were corrected for isotope fractionation.

\section{University of Vienna Laboratory}

The charcoal samples ${ }^{14} \mathrm{C}$-dated at the VERA laboratory were pretreated with the lab's standard ABA method (see e.g., Wild et al. 2008), but for the first $\mathrm{HCl}$ step a higher temperature of $80^{\circ} \mathrm{C}$ instead of the usually used $60^{\circ} \mathrm{C}$ was selected. In the second ${ }^{14} \mathrm{C}$ dating of sample 1048 the standard ABA method-with all pretreatment steps at $60^{\circ} \mathrm{C}$-was applied. The pretreated samples were then combusted at $900^{\circ} \mathrm{C}$ in evacuated/ sealed ampoules in the presence of $\mathrm{CuO}$ and silver wire, and finally graphite targets were prepared. Accelerator mass spectrometry analyses were carried out at the VERA laboratory using the Pelletron 3 MV tandem accelerator (Steier et al. 2004).

\section{Calculation of Radiocarbon Ages}

The measured ${ }^{14} \mathrm{C}$ activities and their uncertainties are expressed as $\mathrm{BP}$ (before present, i.e., before 1950 , as later ${ }^{14} \mathrm{C}$ levels in the biosphere were influenced by atmospheric nuclear weapons tests) ages using the Stuiver and Polach (1977) convention with the Libby ${ }^{14} \mathrm{C}$ half-life of 5568 years. The combined uncertainties (statistical and systematic) of ${ }^{14} \mathrm{C}$ ages are given as one sigma, corresponding to approximately 68\% probability (Currie 2008).

The ${ }^{14} \mathrm{C}$ ages expressed as BP represent are uncalibrated ${ }^{14} \mathrm{C}$ dates (Stuiver and Reimer 1993). Due to past ${ }^{14} \mathrm{C}$ activity fluctuations in the biosphere, these ages should be calibrated using calibration curve IntCal20 obtained from precise ${ }^{14} \mathrm{C}$ measurements in tree-ring samples of know age (Reimer et al. 2020). Uncertainties of calibrated ages associated with the ${ }^{14} \mathrm{C}$ calibration curve are obtained from the conventional ${ }^{14} \mathrm{C}$ ages and their combined uncertainties, which are then converted into calibrated calendar dates with the OxCal 
computer program (Bronk Ramsey 2020). Calibrated ages are expressed as age intervals in AD. The corresponding uncertainties are usually given at $2 \sigma$, representing $95.4 \%$ probability of the given age interval.

Although the ${ }^{14} \mathrm{C}$ ages of dated wood, charcoal, mortar and plaster samples quoted as BP have very small uncertainties (about \pm 20 years), due to the specific plateau character of the calibration curve in the 9th-10th century, the calibrated ages have wider age intervals (as discussed later).

\section{RESULTS}

Results of ${ }^{14} \mathrm{C}$ dating of wood, charcoal, mortar and plaster samples collected from the St. George's Rotunda, obtained from the international consortium laboratories (Table 1), show that a reasonable agreement has been obtained between the participating laboratories for given types of samples. Altogether 20 samples were dated including 6 wood, 3 charcoal, 7 mortar, and 4 plaster samples.

As the preliminary ${ }^{14} \mathrm{C}$ ages of W6 (1041) wood sample and C2 (1042) charcoal sample obtained by gas proportional counting $(1350 \pm 140 \mathrm{BP}$ and $1390 \pm 100 \mathrm{BP}$, respectively) indicated much older ages than expected, an international consortium of ${ }^{14} \mathrm{C}$ laboratories has been formed to carry out more detailed and more precise ${ }^{14} \mathrm{C}$ dating of samples collected at St. George's Rotunda. The AMS ${ }^{14} \mathrm{C}$ ages measured with very high precision confirmed the preliminary results obtained with gas proportional counting.

Similarly, encouraging results were obtained with gas proportional counting of ${ }^{14} \mathrm{C}$ in mortar and plaster samples. Preliminary results showed these ages for mortar and plaster samples: $1520 \pm 50 \mathrm{BP}(\mathrm{M} 2-1045), 1350 \pm 50 \mathrm{BP}(\mathrm{M} 4-1061)$, and $640 \pm 40 \mathrm{BP}(\mathrm{P} 4-1062)$. As these ages were within expectations, it was decided that more precise AMS measurements of mortar and plaster samples will also be carried out in consortium laboratories.

It is important to stress that results for all four sample types (wood, charcoal, mortar and plaster) did not show any inconsistences between the samples and the laboratories. They all agreed within quoted uncertainties and the wood data also passed the chi-square tests $\left(\chi^{2}\right.$ test). Therefore, we proceeded with calculations of calibrated ${ }^{14} \mathrm{C}$ age ranges of analyzed samples with the OxCal v4.4 calibration program (Bronk Ramsey 2020) using the IntCal20 calibration curve (Reimer et al. 2020).

\section{Radiocarbon Dating of Wood Samples}

From the ${ }^{14} \mathrm{C}$ analysis, we may sort six wood samples into three groups (Table 1). The largest group consisting of four wood samples $(1041,1044,1047$ and 1067) shows similar results with conventional (uncalibrated) ages from $1140 \pm 25$ to $1237 \pm 21 \mathrm{BP}$.

The youngest is sample 1043; it gave an average conventional age of $363 \pm 19 \mathrm{BP}$, which is clearly outside of the mean age range obtained from other samples. This is the youngest sample from all the samples analyzed in this work. The explanation of this age is simple as this sample represented a small twig ( $2 \mathrm{~mm}$ in diameter and $30 \mathrm{~mm}$ long) found in the surface plaster at the apse, which was probably added there with a new plaster during restoration of the interior Rotunda coating. Therefore, the sample W1 (1043) will not be included in calculations of the calibrated dates. 
Table 1 Results of ${ }^{14} \mathrm{C}$ dating of wood $(\mathrm{W})$, charcoal (C), mortar (M), and plaster (P) samples from the St. George's Rotunta in Nitrianska Blatnica.

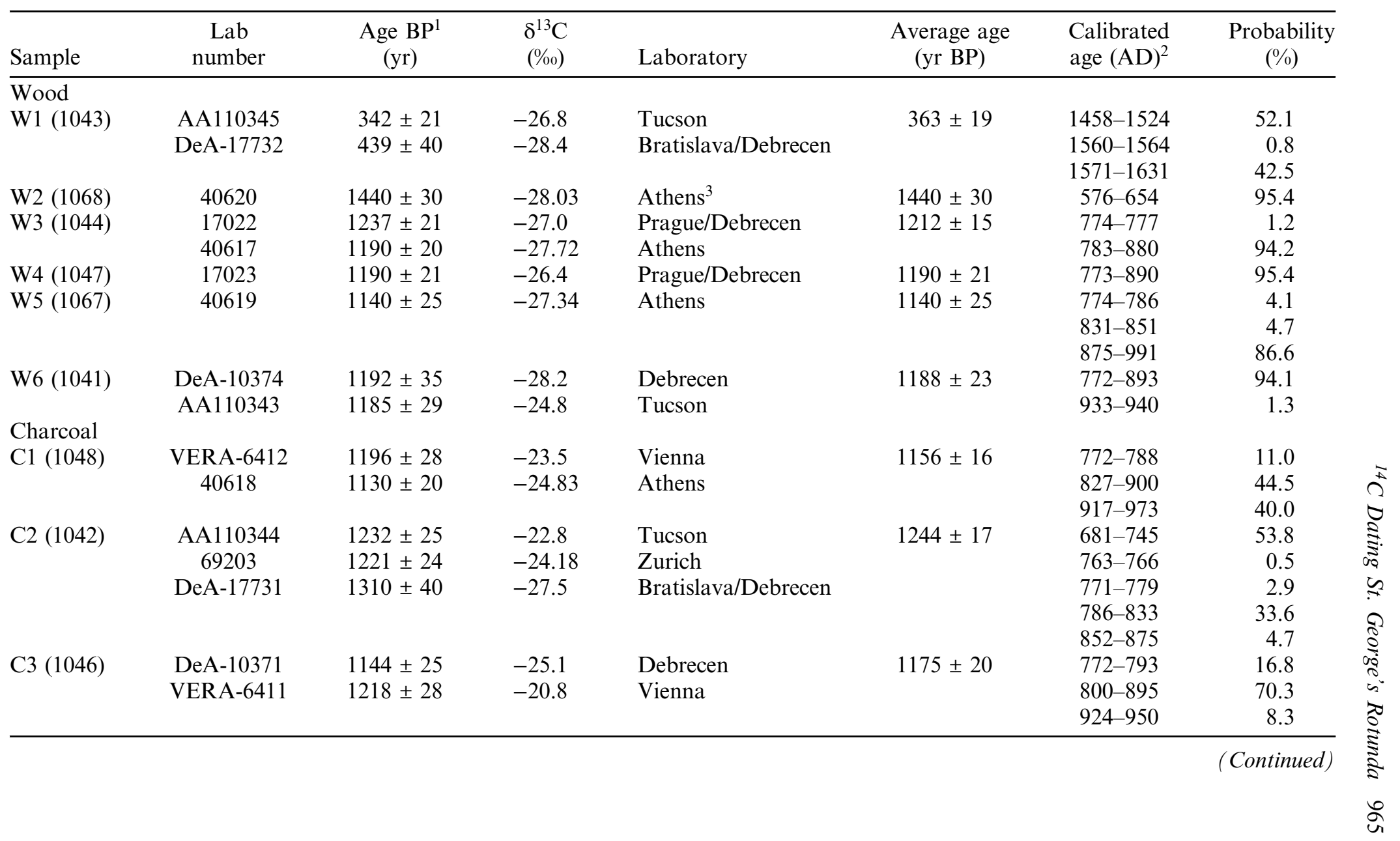


Table 1 (Continued)

\begin{tabular}{|c|c|c|c|c|c|c|c|}
\hline Sample & $\begin{array}{c}\text { Lab } \\
\text { number }\end{array}$ & $\begin{array}{c}\text { Age } \mathrm{BP}^{1} \\
(\mathrm{yr})\end{array}$ & $\begin{array}{l}\delta^{13} \mathrm{C} \\
(\% 0)\end{array}$ & Laboratory & $\begin{array}{l}\text { Average age } \\
\text { (yr BP) }\end{array}$ & $\begin{array}{l}\text { Calibrated } \\
\text { age }(A D)^{2}\end{array}$ & $\begin{array}{c}\text { Probability } \\
(\%)\end{array}$ \\
\hline \multicolumn{8}{|l|}{ Mortar } \\
\hline M1 (1049) & 69199 & $1267 \pm 72$ & -27.8 & Zurich & NA* & & \\
\hline M2 (1045) & 69200 & $1127 \pm 61$ & -22.8 & Zurich & $1127 \pm 61$ & $772-1027$ & 95.4 \\
\hline \multirow[t]{3}{*}{ M3 (1069) } & 69201 & $1080 \pm 125$ & -30.2 & Zurich & $1080 \pm 125$ & $679-748$ & 6.8 \\
\hline & & & & & & $758-1181$ & 87.0 \\
\hline & & & & & & $1188-1210$ & 1.7 \\
\hline \multirow[t]{2}{*}{ M4 (1061) } & 40606 & $1091 \pm 23$ & 26.65 & Bratislava/Athens & $1091 \pm 23$ & $892-996$ & 91.1 \\
\hline & & & & & & $1006-1016$ & 3.3 \\
\hline \multirow[t]{2}{*}{ M5 (1063) } & 40608 & $1150 \pm 24$ & NA & Bratislava/Athens & $1150 \pm 24$ & $773-788$ & 7.3 \\
\hline & & & & & & $827-978$ & 88.1 \\
\hline \multirow[t]{2}{*}{ M6 (1064) } & 40609 & $1260 \pm 23$ & -26.24 & Bratislava/Athens & $1260 \pm 23$ & $672-778$ & 82.3 \\
\hline & & & & & & $788-826$ & 13.1 \\
\hline M7 (1070) & 40612 & $1106 \pm 23$ & NA & Bratislava/Athens & $1106 \pm 23$ & 891-993 & 95.4 \\
\hline \multicolumn{8}{|l|}{ Plaster } \\
\hline P1 (1065) & 40610 & $927 \pm 23$ & NA & Bratislava/Athens & $927 \pm 23$ & $1035-1175$ & 95.4 \\
\hline \multirow[t]{4}{*}{ P2 (1050) } & 69202 & $1114 \pm 83$ & -19.9 & Zurich & $1114 \pm 83$ & $684-744$ & 5.0 \\
\hline & & & & & & $771-1048$ & 86.8 \\
\hline & & & & & & $1083-1129$ & 3.0 \\
\hline & & & & & & $1139-1150$ & 0.6 \\
\hline \multirow[t]{2}{*}{ P3 (1066) } & 40611 & $580 \pm 23$ & NA & Bratislava/Athens & $580 \pm 23$ & $1308-1363$ & 67.1 \\
\hline & & & & & & $1386-1413$ & 28.4 \\
\hline P4 (1062) & 40607 & $425 \pm 22$ & 28.24 & Bratislava/Athens & $425 \pm 22$ & $1431-1490$ & 95.4 \\
\hline
\end{tabular}

${ }^{1}$ Uncertainties at $1 \sigma$.

${ }^{2}$ Calibrated calendar dates calculated with the OxCal computer program (Bronk Ramsey 2020) using the IntCal13 calibration curve (Reimer et al. 2020). Probability ranges at $95.4 \%(2 \sigma$ confidence levels $)$.

${ }^{3}$ Athens (Georgia, USA).

*NA - not available; only the result of AMS analysis of the 4th fraction is available. 
IntCal13

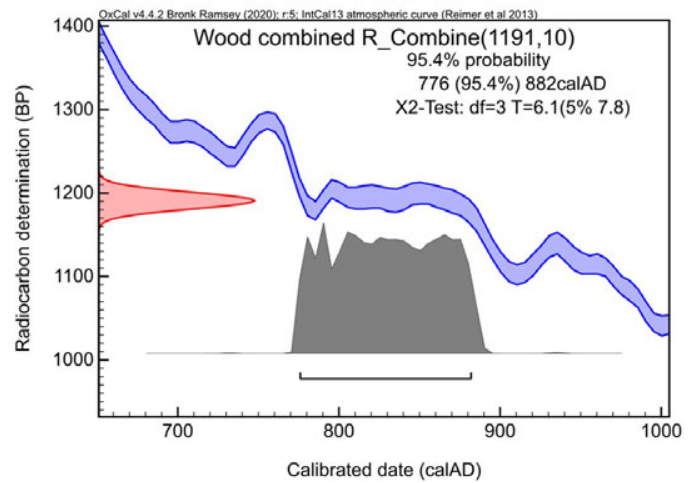

IntCal20

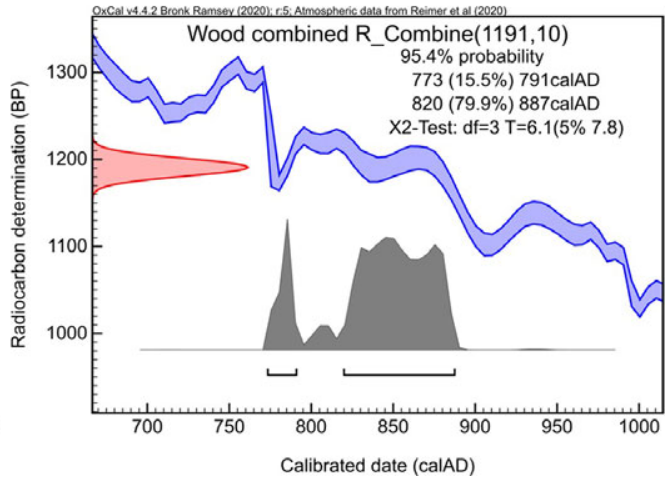

Figure 7 Comparison of wood ${ }^{14} \mathrm{C}$ data calculated using the old IntCal13 and the new IntCal20 calibration.

The oldest collected wood is sample W2 (1068) with conventional age of $1440 \pm 30$ BP. If we calculate the weighted average of 1041, 1044, 1047, and 1067 samples (without sample 1068), we get the age of $1191 \pm 10 \mathrm{BP}$. If we include sample 1068, the weighted average will change to $1217 \pm 10$ BP, i.e., the results obtained are still within statistical uncertainties $(2 \sigma)$, but in the last case the data set will not pass the $\chi^{2}$ test $(T=69.6,5 \%$ critical value 9.5$)$. Therefore, we shall not include sample W2 (1068) in the final evaluation of the age of wood samples. The remaining data passed the $\chi^{2}$ test $(\mathrm{T}=6.1,5 \%$ critical value 7.8$)$. The reason why sample W2 (1068) could look older may be in a lower precision of its analysis ( $\pm 30 \mathrm{yr}$ vs. \pm 20 for most of other samples), and/or it may represent old-wood effect. Such variations in ages of wood samples could be understood well when dating small pieces of wood (representing only 1-2 annual rings used for AMS measurements), taken either from central or outer parts of large trees of several tens of years old.

Taking the weighted average age of $1191 \pm 10 \mathrm{BP}$, the result in the form of a combined calibration diagram presented in Figure 7 shows that the calibrated calendar age range of the dated wood samples is $820-887$ AD (with $79.9 \%$ probability).

\section{Radiocarbon Dating of Charcoal Samples}

Unfortunately, only three charcoal samples were found in the Rotunda walls during restoration works. ${ }^{14} \mathrm{C}$ dating of all three samples (Table 1) gave results within statistical uncertainties, with average ages of $1244 \pm 17 \mathrm{BP}(1042), 1175 \pm 20 \mathrm{BP}$ (1046), and $1156 \pm 16 \mathrm{BP}$ (1048). Although the data did not pass the $\chi^{2}$ test for the combined age $(T=15.2,5 \%$ critical value 6.0$)$, the combined calibration diagram of charcoal data is very similar to the wood one, suggesting the approximate combined calibrated calendar age range of the dated charcoal samples of (820-886 AD, 78.8\% probability), which is almost the same as the combined calibrated age range of wood samples (820-887 AD, $79.9 \%$ probability).

As the calibrated ${ }^{14} \mathrm{C}$ ages of wood and charcoal samples are very similar, we could calculate the combined wood and charcoal calibrated age. As expected, the result is almost the same as for the separate wood and charcoal data, 820-886 (80.7\% probability). This consistency in ${ }^{14} \mathrm{C}$ calibrated ages of wood and charcoal samples is remarkably good, as can be also seen in Figure 8 . 


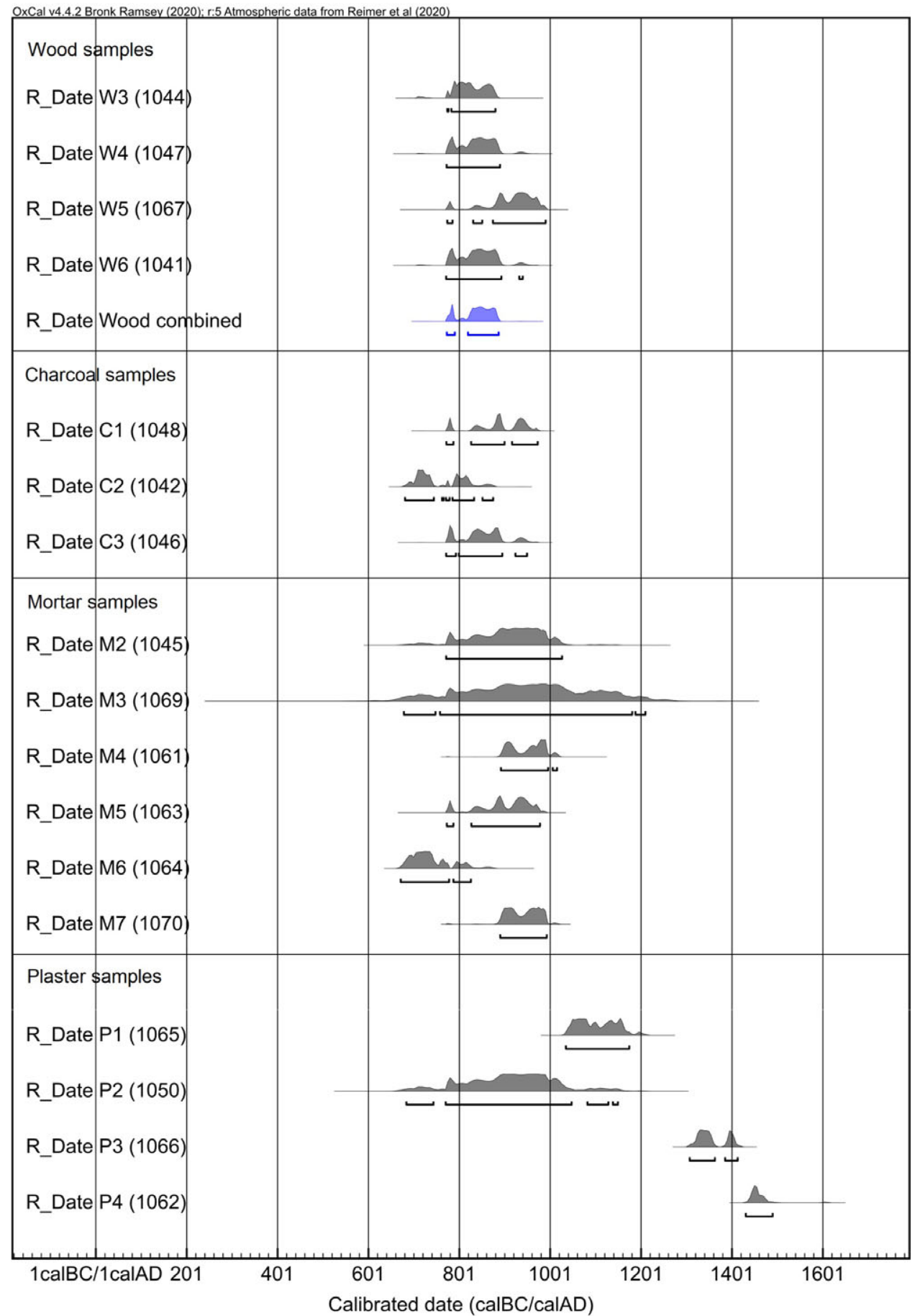

Figure 8 Comparison of ${ }^{14} \mathrm{C}$ calibrated dates for wood, charcoal, mortar, and plaster samples calculated using IntCal20 calibration. 
Table 2 Results of sequentional ${ }^{14} \mathrm{C}$ analysis of mortar (M) and plaster (P) samples carried out by ETH Zurich.

\begin{tabular}{|c|c|c|c|c|c|c|c|c|}
\hline \multirow[b]{2}{*}{ Sample } & \multirow[b]{2}{*}{$\begin{array}{c}\text { Lab } \\
\text { number }\end{array}$} & \multicolumn{5}{|c|}{ Age $\mathrm{BP}^{1}(\mathrm{yr})$} & \multirow[b]{2}{*}{$\begin{array}{l}\delta^{13} \mathrm{C} \\
(\%)\end{array}$} & \multirow[b]{2}{*}{$\begin{array}{c}\text { Accepted } \\
\text { age (yr) }\end{array}$} \\
\hline & & $\begin{array}{c}1 \text { st } \\
\text { fraction }\end{array}$ & 2nd fraction & $\begin{array}{c}\text { 3rd } \\
\text { fraction }\end{array}$ & $\begin{array}{c}4 \text { th } \\
\text { fraction }\end{array}$ & Bulk & & \\
\hline \multicolumn{9}{|l|}{$\overline{\text { Mortar }}$} \\
\hline M1 (1049) & 69199 & $\mathrm{NA}^{2}$ & NA & NA & $1267 \pm 72$ & $1871 \pm 72$ & $\begin{array}{l}-27.8 \\
-10.7\end{array}$ & NA \\
\hline M2 (1045) & 69200 & NA & $1127 \pm 61$ & $1262 \pm 76$ & $1279 \pm 70$ & $1268 \pm 21$ & $\begin{array}{l}-22.8 \\
-19.1 \\
-11.4 \\
-12.8\end{array}$ & $1127 \pm 61$ \\
\hline M3 (1069) & 69201 & $1080 \pm 125$ & NA & NA & NA & $1283 \pm 21$ & $\begin{array}{l}-30.2 \\
-12.3\end{array}$ & $1080 \pm 125$ \\
\hline Plaster & & & & & & & & \\
\hline P2 (1050) & 69202 & NA & $1114 \pm 83$ & $1018 \pm 63$ & $1059 \pm 89$ & $1206 \pm 22$ & $\begin{array}{r}-19.9 \\
-11.1 \\
-10.0 \\
-7.9\end{array}$ & $1114 \pm 83$ \\
\hline
\end{tabular}

${ }^{1}$ Uncertainties at $1 \sigma$.

${ }^{2} \mathrm{NA}$ - not available; too small $\mathrm{CO}_{2}$ volumes for AMS analysis. 


\section{Radiocarbon Dating of Mortar Samples}

Seven mortar samples were analyzed using sequential method with per partes absorption of released $\mathrm{CO}_{2}$ (Table 1). Table 2 lists detail results for three mortars and one plaster sample obtained by the Zurich group. As for M1 (1049) sample only the 4th fraction was available for AMS measurements, which resulted in conventional age of $1267 \pm 72 \mathrm{BP}$ (the age of bulk sample was $1871 \pm 72 \mathrm{BP}$ ), this result was not included in the final data set for estimation of the age of mortar samples, as it could be influenced by fossil calcite (Hajdas et al. 2020). The accepted result from the 1st fraction of M3 (1069) sample (1080 \pm 125 $\mathrm{BP})$, and from the 2nd fraction of M2 (1045) sample (1127 $\pm 61 \mathrm{BP})$ gave conventional ages in a reasonable agreement with ages of other mortar samples 1061, 1063, 1064, and $1070(1091 \pm 23 \mathrm{BP}, 1150 \pm 24 \mathrm{BP}, 1260 \pm 23 \mathrm{BP}, 1106 \pm 23 \mathrm{BP}$, respectively), obtained by Bratislava/Athens groups. They used combined 1 st and 2 nd fractions of released $\mathrm{CO}_{2}$ which was converted to graphite for AMS measurements.

As expected, the ${ }^{14} \mathrm{C}$ dating results of mortar samples have a wider range of conventional ages (from $1091 \pm 23 \mathrm{BP}$ to $1260 \pm 23 \mathrm{BP}$ ) than wood and charcoal samples (Table 1). Although the $\chi^{2}$ test for the combined mortar samples fails $(\mathrm{T}=33.8,5 \%$ critical value 11.1$)$, the approximate combined calibrated age of $873-973 \mathrm{AD}(79.7 \%$ probability) is in a reasonable agreement with ages derived from wood and charcoal samples (Figure 8), having in mind that mortar dating results show larger variability than data obtained from wood and charcoal.

Although the ${ }^{14} \mathrm{C}$ dating of mortar samples is still a challenging method, recently new developments have been reported (e.g., Hajdas et al. 2020; Urbanová et al. 2020), which will further improve dating of mortars. The dating results of mortar samples reported in this work confirmed usefulness of the method, especially if the mortar data could be supported by wood and/or charcoal data. Fortunately, in one mortar sample (M4 (1061)) a piece of charcoal was found (C1 (1048)) which gave the age of $1156 \pm 16 \mathrm{BP}$, in agreement within $2 \sigma$ with the corresponding mortar age of $1091 \pm 23 \mathrm{BP}$.

\section{Radiocarbon Dating of Plaster Samples}

Four plaster samples were ${ }^{14} \mathrm{C}$ dated with ages from $425 \pm 20 \mathrm{BP}$ to $1114 \pm 83 \mathrm{BP}$ (Table 1). Such a wide range of ages was expected due to the several reconstructions carried out during the Rotunda history. The oldest plaster sample P2 (1050) may represent the original plaster applied during the Rotunda construction as its calibrated age range of 771-1048 AD (86.8\% probability) agrees reasonably well with calibrated age ranges of the mortar samples (875-974 AD, 83.4\% probability). The other calibrated ages of plaster samples given in Table 1 (1034-1160 AD (95.4\%) for 1065, 1308-1363 AD (67.1\%) for 1066, and 1431-1490 AD (95.4\% probability) for 1062), may indicate time framework of reconstruction works which were carried out in the interior of the Rotunda.

\section{Comparison of Radiocarbon Calibrated Dates for Wood, Charcoal, Mortar, and Plaster Samples}

Figure 8 shows the calibrated age ranges of accepted wood, charcoal, mortar and plaster samples. It can be seen that the age ranges are well overlapping (except three plaster samples as already discussed), which indicate an agreement that the Rotunda was constructed in the 9th century. The best data set was obtained for four wood samples (passing $\chi^{2}$ test), giving the combined calibrated age range of $820-887 \mathrm{AD}$ (79.9\% probability). 
This age range is in good agreement with the single oldest calibrated age range obtained for W3 (1044) wood sample, 783-880 AD (94.2\% probability), which was measured with high precision. Therefore, this result may be accepted as possible date interval for the Rotunda construction.

The calibrated age ranges obtained for three charcoal samples are from $681-745$ AD (53.8\% probability) to $827-900$ AD (44.5\% probability), showing wide age ranges with lower probabilities. As the combined data did not pass the $\chi^{2}$ test, we can calculate only an approximate combined age range of $820-886 \mathrm{AD}$ (78.8\% probability), which is almost the same as the combined age range of wood samples, $820-887$ AD (79.9\% probability).

The calibrated age ranges of six mortar samples from $672-778$ AD (82.3\% probability) to 758-1181 AD (87.0\% probability) are much wider than for wood and charcoal samples, however, they are in a reasonable agreement with ages derived from wood and charcoal samples (Figure 8).

The calibrated age ranges of three plaster samples are in the intervals of $1034-1160$ AD (95.4\% probability), 1308-1363 AD (67.1\% probability), and 1431-1490 AD (95.4\% probability). They clearly indicate different reconstruction phases of the Rotunda interior, which are, however, difficult to identify in its history. Only one plaster sample, P2 (1050), of the calibrated age range of $771-1048 \mathrm{AD}(86.8 \%$ probability), is close to the combined age ranges of wood and charcoal samples, which may indicate its origin during the Rotunda construction.

\section{DISCUSSION}

\section{Radiocarbon Calibration Curve}

The specific character of the calibration curve during the 9th century (Figure 7) has negative impact on the precision of calibrated ages as the range of AD calibrated ages is almost 100 years (for IntCal13). Between 800-880 AD, the curve shows a plateau with almost the same ${ }^{14} \mathrm{C}$ conventional age around $1190 \mathrm{BP}$, with $1 \sigma$ uncertainties of single measurements around $\pm 20 \mathrm{yr}$ (for the weighted mean averages around $\pm 10 \mathrm{yr}$ ). This behavior of the calibration curve with resulting uncertainties of calibrated ages prevents establishing a more precise date of the historical events which occurred during the 9th century. Fortunately, the new calibration curve IntCal20 improves the situation when compared with IntCal13 (Figure 7). The calibrated age ranges decreased for example for combined wood samples from $776-882$ AD (95.4\% probability) to $820-887$ AD (79.9\% probability) when calculated using IntCal20.

Unfortunately, the large uncertainty in ${ }^{14} \mathrm{C}$ calibrated ages influences research on the history of the Great Moravia, which plays important role in the Czech and Slovak history. Therefore, a more precise ${ }^{14} \mathrm{C}$ calibration curve for the 9th century is under development which would improve the calibrated age data.

\section{${ }^{14} \mathrm{C}$ Age of Rotunda vs. ${ }^{14} \mathrm{C}$ Age of Wood and Charcoal Samples}

As the trees could be several tens of years old, dating a bulk sample composite of tree rings of unknown trees can modify a true age of dated objects. For example, if an old tree was used for making a fire, and a sample used for dating was from the central part of the tree, the 
corresponding age could be too old when compared with the true age. This age uncertainty should always be in mind when dating objects on the basis of wood dating.

Unfortunately, in our case we have only one very thin sample of sprig or twig ( $2 \mathrm{~mm}$ in diameter and $30 \mathrm{~mm}$ long) found in surface plaster at the apse (1043), which we could present as one year of growth. The ${ }^{14} \mathrm{C}$ calibrated age of this wood is, however, only 1458 $1631 \mathrm{AD}$ (95.4\% probability), indicating that this piece of wood was added into the plaster during reconstruction works carried in the 16 th- 17 th century. The ${ }^{14} \mathrm{C}$ calibrated ages of other wood and charcoal samples are from 773-890 AD (95.4\% probability) up to 576-654 AD (95.4\% probability), with the combined average age of 776-882 AD (95.4\% probability). Clearly, the wood sample W2 (1068) with the oldest calibrated age of 576-654 AD may represent an older wood used during construction works. Its age may be influenced, therefore, by old-wood effect and/or by a larger uncertainty of measurement. If we expect that a typical wood which was used for construction purposes or for making fire would be about 50 years, the resulting uncertainty in the age of wood would be already included in the dating result (taking into account $2 \sigma$ uncertainty).

As we already pointed out, the ${ }^{14} \mathrm{C}$ calibrated ages obtained have very wide range because of the plateau in the calibration curve, i.e., 820-887 AD for wood samples and 820-886 AD for charcoal samples. Therefore, the uncertainty in the age of trees which produced wood and charcoal samples has already been covered in the range of the wood and charcoal calibrated ages. Supporting evidence for the estimation of the true Rotunda age on the basis of wood and charcoal samples can be also obtained from ${ }^{14} \mathrm{C}$ dating of mortar samples and the oldest plaster sample. The calibrated ages of the mortar samples are from 758-1181 AD (87.0\% probability) up to $672-778$ AD $(82.3 \%$ probability), and the calibrated age of the oldest plaster P2 (1050) of $771-1048$ AD (86.8\% probability) are in a reasonable agreement with the combined calibrated age range of wood (820-887 AD, $79.9 \%$ probability) and charcoal ( $820-886 \mathrm{AD}, 78.8 \%$ probability) samples.

We may conclude that the uncertainty in the age of wood used during the construction of the Rotunda is well represented in the calculated mean ranges of ${ }^{14} \mathrm{C}$ calibrated ages of wood, therefore, we can exclude possible old-wood effects on these dates.

The final age of the Rotunda can be based on the earliest time of its construction, represented by wood sample W3 (1044) which gives the oldest date measured with highest precision (1215 $\pm 15 \mathrm{BP}$ ), giving the calibrated age range of 783-880 AD (with $94.2 \%$ probability). This age is in good agreement with the calibrated age range of combined wood (820-887 AD, $79.9 \%$ probability) and charcoal (820-886 AD, 78.8\% probability) samples.

\section{Age of the St. George's Rotunda in Historical Context}

Although the experimental uncertainties associated with ${ }^{14} \mathrm{C}$ determinations were reasonably low (mostly about $\pm 20 \mathrm{yr}$ for single measurement), the resulting wide age range of the Rotunda was influenced by the specific shape of the ${ }^{14} \mathrm{C}$ calibration curve. The results of ${ }^{14} \mathrm{C}$ measurements of the international consortium showed a consistency between the laboratories when analyzing samples of different origin. On the basis of these analyses the radiocarbon calibrated age of the Rotunda was determined to be in the range of 783-880 AD (94.2\% probability). The ${ }^{14} \mathrm{C}$ dating places the construction of the Rotunda (with about $86 \%$ probability) within the period of the first half of the 9th century when Christianity was accepted in some of the Central Europe countries (Goldberg 2006). 
According to historical documents (Anonymous, 870 AD), Salzburg Archbishop Adalram consecrated (in 828 AD) a church in Nitrava (presently Nitra), built by Prince Pribina, a ruler of Principality of Nitrava, which was situated in the western part of the present Slovakia. Prince Pribina was thus the first ruler of Slavic origin who according to written documents built a first Christian church of western Slavs living in the eastern part of the Central Europe. Unfortunately, the existence of this church is documented only in writing as it was probably later incorporated into a chapel, which after several reconstructions became a part of the Cathedral Basilica of St. Emmeram in Nitra. Therefore, the Rotunda of St. George could be the second, still standing church built by Prince Pribina in the Principality of Nitra at Nitrianska Blatnica, only $35 \mathrm{~km}$ from its capital Nitra.

${ }^{14} \mathrm{C}$ dating shows that the Rotunda might well be constructed before the arrival of Constantine (St. Cyril) and St. Methodius to Moravia in 863, after King Rastislav's (ruler of Great Moravia in 846-870) request for teachers to the Byzantine emperor Michael III in Constantinople. Christianity in Central Europe considerably expanded after this mission, also due to the creation of the Glagolitic alphabet and translation of the New Testament, as well as the Christian liturgy to Slavonic language. All these historical events had great impact on the cultural and social developments during and after the Great Moravia times, when many Christian churches were built (Spiesz and Caplovic 2006). Also, an approval of the Slavonic liturgy in 868 by Pope Adrian II as the fourth official liturgical language, after Hebrew, Greek and Latin (Terry and Gallagher 2017) was a great event which helped to spread Christianity in Central and Eastern Europe. It took eleven hundred years (after the II Vatican Council in 1963), when Latin was replaced as the liturgical language by national languages.

The Rotunda of St. George in this respect represents probably the oldest standing church (although after heavy reconstructions) not only in the present Slovakia, but also in the eastern part of the Central Europe. There are two more surviving churches in the territory of the Principality of Nitra which were probably also built during the 9th-10th century. One is close to a small village Kopčany (just across the Morava river is the Great Moravian archaeological site Mikulčice) which was dendrochronologically dated to the beginning of the second half of the 10 th century, and a preliminary ${ }^{14} \mathrm{C}$ dating gave an age of $1025 \pm 60 \mathrm{BP}$, i.e., in agreement within statistical uncertainty (Bahýl et al. 2013). The second one is in Kostolany pod Tríbečom, which was according to ${ }^{14} \mathrm{C}$ dating built at latest in the first quarter of the 10th century (Barta et al. 2015). There are also well documented remains of basements of churches from the Great Moravian period in Bratislava (a three-nave basilica), in Devín (a one-nave church) and in Ducové (a rotunda) (Botek 2015). Unfortunately, no standing churches were preserved at the main archaeological sites of Great Moravia in Velegrad and Mikulčice.

\section{CONCLUSIONS}

Restoration of the St. George's Rotunda in Nitrianska Blatnica (Slovakia) during 2009-2016 generated significant construction-historical findings. Originally it was estimated that the Rotunda was built in the 16th century, then in the 11th century, and later investigations showed that it could be of 9 th-10th century origin. An original window opening was discovered, along with a large fragment of the first layer of plaster with two painted consecration crosses, which together with other findings have moved the origin of the Rotunda to the pre-Romanesque period. 
Therefore, an international consortium of ${ }^{14} \mathrm{C}$ laboratories (Athens and Tucson (USA), Debrecen (Hungary), Prague (Czech Republic), Vienna (Austria), Zürich (Switzerland), and Bratislava) was established in 2017 to date the origin of the Rotunda. Altogether 20 samples of wood, charcoal, mortar and plaster were analyzed. The obtained ${ }^{14} \mathrm{C}$ results between the laboratories as well as between the different sample types were in good agreement. On the basis of ${ }^{14} \mathrm{C}$ analyses of wood samples (in agreement with charcoal results), the final calibrated age of the Rotunda was determined on the basis of the oldest wood sample to be in the range of $783-880 \mathrm{AD}$ (94.2\% probability), which is in agreement with recent archeological investigations.

A summary of the new knowledge and analogies allows us to place the creation of the rotunda to within the era from the first half of the 9th century to the Great Moravian period. In regard to cultural and historical significance, it is interesting whether the Rotunda was built before or after the arrival of Constantine (St. Cyril) and St. Methodius to Great Moravia in 863, because they represent a significant milestone in the Christian history of Central Europe. However, due to a plateau observed in the calibration curve for this time period, it is not possible at present to conclusively place the origin of St. George's Rotunda before this event. Probability distribution from OxCal calibration shows that about $86 \%$ of the probability distribution lies in the period before 863 AD.

The obtained ${ }^{14} \mathrm{C}$ age makes the Rotunda probably the oldest existing Christian structure in Slovakia, and possibly also in eastern Central Europe. It represents a unique sacral structure of historical importance that places it among the most precious Slovak national cultural monuments. It has been a well-known Christian site, continuously visited from the 16th century by many people on St. George's day (24th April), which makes the Rotunda the oldest pilgrimage site in Slovakia.

Present knowledge of the St. George's Rotunda and existence of its long extinct settlement which created a significant territorial complex, is not yet exhausted. The whole locality offers further possibilities for archaeological research as well as further search through archival sources. Perhaps the future will bring new discoveries and expand and refine our knowledge, not only about the St. George's Rotunda in Nitrianska Blatnica and its surrounding, but also about similar historical sites in Central Europe.

\section{ACKNOWLEDGMENTS}

Authors are grateful to Mr. M. Toman (mayor of Nitrianska Blatnica) and the Civic Association of the Rotunda Jurko for support and assistance during restoration works and collection of samples. Prof. A. Ruttkay is acknowledged for useful discussions. Colleagues in participating ${ }^{14} \mathrm{C}$ laboratories are acknowledged for assistance during preparation and measurement of samples. Restoration works on the St. George's Rotunda carried out in 2009-2016 were partially financed by the Ministry of Culture of the Slovak Republic. The Bratislava group also acknowledges a support provided by the EU Research and Development Operational Program funded by the ERDF (projects No. 26240120012, 26240120026, and 26240220004), by the Advancing University Capacity and Competence in Research, Development, and Innovation (ACCORD) ITMS2014 (project no. 313021X329), by the International Atomic Energy Agency's Technical Cooperation Program (project No. SLR/1001, and by the Slovak Research and Development Agency (project No. APVV- 15-0576). The Debrecen group acknowledges support from the 
European Union and the State of Hungary, co-financed by the European Regional Development Fund in the project of GINOP-2.3.2-15-2016-00009 "ICER." The Prague group acknowledges support provided by OP RDE, MEYS of the Czech Republic, under the project Ultra-trace isotope research in social and environmental studies using accelerator mass spectrometry (RAMSES), No. CZ.02.1.01/0.0/0.0/16_019/0000728.

\section{REFERENCES}

Anonymous. 870. Libellus de conversione Bagoariorum et Carantanorum. In: Lukačka J, editor. 1999. Sources of Slovak History and Slovaks II. Bratislava. p. 139-144. In Slovak.

Bahýl V, Fleischeer P, Krišták L, Mészáros T, Pastierovič M, Štafura A. 2013. Is Kopčany church from Great Moravia time? Results of dendrochronological studies. Proc. Interdisciplinary Scientific Research for Protection of the Cultural Heritage. Bratislava: SNM. p 151-162. In Slovak.

Barta P, Bóna M, Keleši M. 2015. Chronometric research of masonry of St. George's Church in Kostol'any pod Tríbečom. Archaeologia Historica 40:691-709. In Slovak.

Bóna M, Barta P. 2015. Contribution to dating of the origin of St. George's Rotunda in Nitrianska Blatnica. Archaeologia Historica 40:683-689. In Slovak.

Botek A. 2015. Great Moravia churches in Slovakia. Bratislava: PostScriptum. 200 p. In Slovak.

Bronk Ramsey C. 2020. OxCal program for radiocarbon calibration. https://c14.arch.ox.ac. uk/oxcal.html.

Currie LA. 2008. Detection and quantification capabilities in nuclear analytical measurements. In: Povinec P, editor. Analysis of environmental radionuclides. Amsterdam: Elsevier. p. 49-135.

Dorica J. 2015. Restoration of the Rotunda of St. George at Nitrianska Blatnica. Pamiatky a múzeá 66(3):31-34. In Slovak.

Dorica J. 2017. Vorromanische St. Georg-rundkirche bei Nitrianska Blatnica im lichte der restauratorenforschung und restaurierung und ihre neue eingliederung im rahmen ältester Sakralbauten in der Slowakei. In: Pieta K, Robak Z, editors. New results of research on early Medieval Hillforts. Nitra: VEDA. p. 281-294.

Goldberg E. 2006. Struggle for empire: kingship and conflict under Louis the German, 817-876. Ithaca (NY): Cornell University Press. 388 p.

Gupta SK, Polach HA. 1985. Radiocarbon dating practices at ANU. Canberra: ANU.

Hajdas I. 2008. The Radiocarbon dating method and its applications in Quaternary studies. E \& G Quaternary Science Journal 57:2-24.

Hajdas I, Maurer M, Röttig MB. 2020. Development of ${ }^{14} \mathrm{C}$ dating of mortars at ETH Zurich. Radiocarbon 62:591-600.
Jull AJT, Burr GS, Beck JW, Hodgins GWL, Biddulph DL, Gann J, Hatheway AL, Lange TE, Lifton NA. 2006. Application of accelerator mass spectrometry to environmental and paleoclimate studies at the University of Arizona. In: Povinec PP, editor. Analysis of environmental radionuclides. Amsterdam: Elsevier. p. 3-23.

Jull AJT, Burr GS, Beck JW, Hodgins GWL, Biddulph DL, McHargue LR, Lange TE. 2008. Accelerator mass spectrometry of long-lived light radionuclides In: Povinec $\mathrm{P}$, editor. Analysis of environmental radionuclides. Amsterdam: Elsevier. p. 241-62.

Kontul' I, Ješkovský M, Kaizer J, Šivo A, Richtáriková M, Povinec PP, Čech P, Steier P, Golser R. 2017. Radiocarbon concentration in tree-ring samples collected in the southwest Slovakia (1974-2013). Applied Radiation and Isotopes 126:58-60.

Kouřil P. 2014. Great Moravia and beginnings of Christianity. Brno: Czech. Acad. Sci.

Lange TE, Nordby JA, Murphy PLO, Hodgins GWL, Pearson CL. 2019. A detailed investigation of pretreatment protocols for high precision radiocarbon measurements of annual tree-rings. Nuclear Instruments and Methods B 455:230-233.

Lukačka J. 2002. Formation of aristocracy in west Slovakia. Bratislava: Minor. 156 p. In Slovak.

Lukačka J. 2011. The beginnings of the nobility in Slovakia. In: Teich M, Kováč D, Brown M, editors. Slovakia in history. Cambridge: Cambridge University Press. p. 30-37.

Molnár M, Janovics R, Major I, Orsovszki J, Gönczi $\mathrm{R}$, Veres M, Leonard AG, Castle SM, Lange TE, Wacker L, Hajdas I, Jull AJT. 2013a. Status report of the new AMS ${ }^{14} \mathrm{C}$ sample preparation lab of the Hertelendi Laboratory of Environmental Studies (Debrecen, Hungary). Radiocarbon 55:665-676.

Molnár M, Rinyu L, Veres M, Seiler M, Wacker L, Synal H-A. 2013b. EnvironMICADAS: a mini ${ }^{14} \mathrm{C}$-AMS with enhanced gas ion source interface in the Hertelendi Laboratory of Environmental Studies (HEKAL), Hungary. Radiocarbon 55:338-344.

Orsovszki G, Rinyu L. 2015. Flame-sealed tube graphitization using zinc as the sole reduction agent: precision improvement of Environ 
MICADAS ${ }^{14} \mathrm{C}$ measurements on graphite targets. Radiocarbon 57:979-990.

Povinec P. 1972. Preparation of methane gas filing for proportional ${ }^{3} \mathrm{H}$ and ${ }^{14} \mathrm{C}$ counters. Radiochemical and Radioanalytical Letters 9:127-135.

Povinec P. 1978. Multiwire proportional counters for low level ${ }^{14} \mathrm{C}$ and ${ }^{3} \mathrm{H}$ measurements. Nuclear Instruments and Methods 156:441-445.

Povinec P. 1992. ${ }^{14} \mathrm{C}$ gas counting: Is there still a future? Radiocarbon 34:406-413.

Povinec PP, Masarik J, Ješkovský M, Kaizer J, Šivo A, Breier R, Pánik J, Staníček J, Richtáriková M, Zahoran M, Zeman J. 2015. Development of the accelerator mass spectrometry technology at the Comenius University in Bratislava. Nuclear Instruments and Methods in Physics Research B361:87-94.

Ragač R. 2009. Contribution to the early history of the St. George's church in Nitrianska Blatnica from archive sources. Monumentorum Tutela 22:358-363. In Slovak.

Reimer PJ et al. 2020. IntCal20 Northern Hemisphere radiocarbon age calibration curve $(0-55$ cal $\mathrm{kBP})$ and Marine13 radiocarbon age calibration curves $0-50,000$ years cal BP. Radiocarbon 62:725-757.

Rejthar R. 1975. Nitrianska Blatnica, Rotunda sv. Juraja. In: central monument archive of Slovak Republic. Bratislava.

Rinyu L, Molnár M, Major I, Nagy T, Veres M, Kimák Á, Wacker L, Synal H-A. 2013. Optimization of sealed tube graphitization method for environmental ${ }^{14} \mathrm{C}$ studies using MICADAS. Nuclear Instruments and Methods in Physics Research B294:270-275.

Rinyu L, Orsovszki G, Futó I, Veres M, Molnár M. 2015. Application of zinc sealed tube graphitization on sub-milligram samples using Environ MICADAS. Nuclear Instruments and Methods in Physics Research B361:406-413.

Ruff M, Szidat S, Gäggeler H, Suter M, Synal HA, Wacker L. 2010. Gaseous radiocarbon measurements of small samples. Nuclear Instruments and Methods B268:790-794.

Ruttkay A. 1975. Frühmittelalterliche Rotunde und Siedlungswüstung bei Nitrianska Blatnica. In: Chropovský B, editor. AVANS. Nitra: SAV Publ. p. 94-96. In Slovak.

Ruttkay A. $1977 . \quad$ Erforschung von Frühmittelalterlicher Siedlung, Architectur und Gräberfeld bei Nitrianska Blatnica im Jahre
1976. In: Chropovský B, editor. AVANS. Nitra: SAV Publ. p. 243-251.

Ruttkay A. 1980. Grabungsergebnisse in Nitrianska Blatnica im 1979. In: Chropovský B, editor. AVANS. Nitra: SAV Publ. p. 185-190. In Slovak.

Ruttkay A. 1998. Zur frühmittelalterlichen Hof-, Curtis und Curia regalis - Frage in der Slowakei. In: Henning J, Ruttkay AT, editors. Frühmittelalterlicher Burgenbau in Mittel- und Osteuropa. Bonn. p. 405-417.

Ruttkay AT. 2014. Nitrianska Blatnica. Slovakia. In: Kouřil P, editor. Great Moravia and beginnings of Christianity. Brno: Czech. Academy Sci. p. 238-241. In Slovak.

Ruttkay AT. 2015. Nitrianska Blatnica. der Ursprung und die geschichte der hl. Georg Rotunde und die umliegende Besiedlung im 9.-13. jahrhundert nach dem archäologische Forschungen. In: Pieta K, Robak Z, editors. New Results of Research on Early Medieval Hillforts. Nitra: VEDA. p. 233-246.

Schneider RJ, McNihol AP, Nadeau MJ, Reden KF. 1995. Measurements of the Oxalic Acid II/Oxalic Acid I ratio as a quality control parameter at NOSAMS. Radiocarbon 37(2):693-696.

Spiesz A, Caplovic D. 2006. Illustrated Slovak history: a struggle for sovereignty in Central Europe. Wauconda, Illinois: Bolchazy-Carducci Publishers. 420 p.

Steier P, Dellinger F, Kutschera W, Priller A, Rom W, Wild EM. 2004. Pushing the precision limit of ${ }^{14} \mathrm{C}$ AMS. Radiocarbon 46:5-16.

Stuiver M, Polach H. 1977. Reporting of ${ }^{14} \mathrm{C}$ data. Radiocarbon 19:355-363.

Stuiver M, Reimer PJ. 1993. Extended ${ }^{14} \mathrm{C}$ data base and revised Calib $3.0{ }^{14} \mathrm{C}$ age calibration program. Radiocarbon 35:215-230.

Terry JM, Gallagher RL. 2017. Encountering the History of missions. Grand Rapids: Baker Academic. 406 p.

Urbanová P, Boaretto E, Artioli G. 2020. The stateof-the-art dating techniques applied to ancient mortars and binders: a review. Radiocarbon 62:503-525.

Vogel JS, Southon JR, Nelson DE, Brown TA. 1984, Performance of accelerator mass spectrometry. Nuclear Instruments and Methods in Physics Research B5:289-293.

Wild EM, Neugebauer-Maresch C, Einwögerer T, Stadler P, Steier P, Brock F. 2008. ${ }^{14} \mathrm{C}$ dating of the Upper Paleolithic site at Krems-Hundssteig in Lower Austria. Radiocarbon 50:1-10. 